\title{
Transdermal ketoprofen mitigates the severity of postoperative sore throat
}

\section{[Le kétoprofêne transdermique réduit le mal de gorge postopératoire]}

Masayuki Ozaki MD, Kouichiro Minami MD PhD, Takeyoshi Sata MD PhD, Akio Shigematsu MD PhD

Purpose: To evaluate prospectively the incidence and severity of postoperative sore throat in 63 orotracheally intubated patients undergoing general anesthesia for various surgical procedures and to determine whether postoperative sore throat could be attenuated by treatment with the transdermal nonsteroidal anti-inflammatory drug ketoprofen applied on the anterior skin of the neck during operation.

Method: Patients were randomly assigned to have treatment with ketoprofen (ketoprofen group) or to have placebo tape treatment (control group). Postoperative analgesia was obtained by continuous epidural infusion of local anesthetics, and no narcotics were administered intraoperatively or postoperatively. All patients were interviewed postoperatively after 12-20 hr using a scoring scale questionnaire. Sore throat was scored as $0=$ no sore throat, I =minimal, $2=$ mild, $3=$ moderate, $4=$ severe.

Results: In the control group, 16 of 32 patients had a sore throat. In the ketoprofen group, less patients (ten of 31 patients) had a sore throat (not significant). The severity of sore throat was alleviated significantly in the ketoprofen group $(P<0.05)$.

Conclusion: This study suggests the pain caused by tracheal intur bation is relieved by intraoperative topical use of transdermal ketoprofen.

Objectif : Évaluer de façon prospective l'incidence et la sévérité du mal de gorge postopératoire chez 63 patients soumis à une intubation oro-trachéale et à une anesthésie générale pour différentes interventions chirurgicales. Aussi, déterminer si le mal de gorge postopératoire peut être limité par un traitement avec un anti-inflammatoire non stéroïdien transdermique, le kétoprofene, appliqué sur la peau de la face antérieure du cou pendant l'opération.

Méthode : Les patients ont été répartis au hasard et ont reçu le kétoprofene (groupe kétoprofene) ou une bande placebo (groupe témoin). L'analgésie postopératoire a été obtenue par une perfusion épidurale continue d'anesthésiques locaux. Aucun narcotique n'a été administré pendant ou après l'opération. Tous les patients ont répondu, 12-20 h après l'opération, à un questionnaire doté d'une échelle de cotation. Le mal de gorge était coté comme suit : 0 = aucun mal de gorge, 1 = minime, 2 = léger, 3 = modéré, 4 = sévère.

Résultats : Dans le groupe témoin, 16 des 32 patients ont eu un mal de gorge. Dans le groupe kétoprofene, dix des 31 patients ont eu une mal de gorge (non significatif). La sévérité de cet inconfort a été significativement réduite avec le kétoprofene $(P<0,05)$.

Conclusion : La présente étude suggère que la douleur causée par l'intubation endotrachéale est soulagée par l'usage topique peropératoire de kétoprofene transdermique.

$\mathrm{P}$ OSTOPERATIVE sore throat is a common complication following endotracheal intubation with reported incidences of $6.6 \%-90 \% .^{1-4}$ This minor complication is considered to result from a number of events. Firstly, traumatic laryngoscopy or placement of a nasogastric tube or rough suctioning may injure the pharyngolaryngeal mucosa. ${ }^{5}$ Secondly, cuff design and pressure affect tracheal mucosal capillary perfusion. ${ }^{6-11}$ Thirdly, contact of the tracheal tube with the vocal cords and posterior pharyngeal wall may result in edema or lesion. ${ }^{12}$ Although usually not crucial, the pain from sore throat can be the main complaint when incisional pain is well controlled, particularly by epidural analgesia. To prevent trauma to the pharynx, larynx, and trachea, various measures have been recommended, such as the use of endotracheal tubes with a low intracuff pressure, ${ }^{11,13}$ smaller endotracheal tubes, ${ }^{12}$ steroid coated endotracheal tubes, ${ }^{14}$ inhalation of steroids, ${ }^{15}$ or topical use of lidocaine. ${ }^{16}$

Ketoprofen $\{2$-(3-benzoylphenyl) propionic acid $\}$ belongs to the propionic acid derivatives, which represent a group of analgesic, anti-inflammatory, and

From the Department of Anesthesiology, University of Occupational and Environmental Health, School of Medicine, Fukuoka, Japan. Address correspondence to: Dr. Kouichiro Minami, Department of Anesthesiology, University of Occupational and Environmental

Health, School of Medicine, 1-1, Iseigaoka, Yahatanishiku, Kitakyushu, Fukuoka, 807-8555, Japan. Phone: +81-93-691-7265;

Fax: +81-93-601-2910; E-mail: kminami@med.uoeh-u.ac.jp

Accepted for publication May 29, 2001.

Revision accepted August 29,2001. 
antipyretic nonsteroidal anti-inflammatory drugs (NSAIDs). ${ }^{17}$ It has been reported that ketoprofen is useful for postoperative analgesia. ${ }^{18}$ Recently, application to the skin has been shown to be a suitable delivery route for ketoprofen in the transdermal therapeutic system. ${ }^{19}$ However, transdermal application of NSAID to prevent postoperative sore throat has not been reported. Thus, the aim of our study was to determine whether transdermal application of ketoprofen during surgery prevents sore throat.

Methods

This study was approved by our university Ethics Committee. ASA physical status I or II adult patients presenting for major elective orthopedic surgery of the lower extremities and gynecological surgery were enrolled. Patients who were $<18 \mathrm{yr}$ old or had a history of asthma, coagulopathy, difficult airway, and known hypersensitivity to NSAIDs or adhesive tape were excluded. Informed consent was obtained from all patients. Patients were randomly assigned to receive treatment with ketoprofen (ketoprofen group) or placebo tape (control group).

Triazolam $0.25 \mathrm{mg}$ po was administered preoperatively. Prior to the induction of general anesthesia, an epidural catheter was placed and a local anesthetic was administered intraoperatively and postoperatively in the epidural space. General anesthesia was induced with propofol $2-2.5 \mathrm{mg} \cdot \mathrm{kg}^{-1}$ iv after preoxygenation. Laryngoscopy and tracheal intubation were facilitated with vecuronium $1.0 \mathrm{mg} \cdot \mathrm{kg}^{-1} i v$. Endotracheal tubes with a low-pressure cuff Sheridan $^{\mathrm{TM}}$; Kendall Healthcare Products Co., Inc., Mansfield, MA, USA) were used. Male and female patients received $8.0-\mathrm{mm}$ and 7.5- $\mathrm{mm}$ inner diameter tubes, respectively. A lidocaine $(10 \%)$ containing lubricant was used on endotracheal tubes. Intubations were performed by the same anesthesia resident (supervised by faculty) with a curved laryngoscope. The resident was blinded to group assignment. A patient was eliminated from the study if more than two attempts at passage of the endotracheal tube were required. The cuff was inflated just to the point of obtaining a seal in the presence of positive airway pressure. Intracuff pressure was adjusted every 30 min using a pressure gauge (Digital P-V Gauge ${ }^{\mathrm{TM}}$, IMP, Inc., Cleveland, Ohio, USA) to limit nitrous oxiderelated intracuff pressure increase. ${ }^{20}$ After induction, a transdermal ketoprofen $20 \mathrm{mg}$ (Mohrus ${ }^{\circledR}$ tape; Hisamitsu Pharmaceutical Co., Inc., Tosu, Japan) tape or a placebo tape was applied to the anterior skin of the neck and removed just before emergence (Figure). Ventilation was adjusted to maintain $\mathrm{PaCO}_{2}$ at 35-40 $\mathrm{mmHg}$. Orogastric or nasogastric tubes were not placed. Anesthesia was maintained with isoflurane $0.5-1.5 \%$ in combination with nitrous oxide $67 \%$ in oxygen. Supplemental analgesia was obtained by bolus injection of $2 \%$ mepivacaine into the epidural space every $50 \mathrm{~min}$. Adequate muscle relaxation for the surgical procedure was obtained by epidural anesthesia, and no additional muscle relaxant was used. Oropharyngeal suction before extubation was done under direct vision to avoid trauma to the pharyngeal mucosal tissue. Postoperative analgesia was obtained by continuous epidural infusion of local anesthetics, and no narcotics were administered intraoperatively or postoperatively. Patients' soreness of throat was evaluated 12-20 hr postoperatively by a blinded member of the research team using the questionnaire presented in Tables I and II, modified after the questionnaire suggested by Harding and McVey. ${ }^{21}$ Adverse effects on the digestive system and skin, if any, were noted (Table I). Impairment of platelet function was suspected if the patient had excessive postoperative bleeding.

Results are presented as mean \pm SD or number (percentage) where appropriate. Patient characteristics were analyzed by using Student's t test. Difference in incidence of sore throat was compared using the chi-square test with Yates' correction. Difference in severity of sore throat was compared using the Mann-Whitney U test. A $P$ value of $<0.05$ was accepted as statistically significant. To detect a difference with a power 0.8 and $=0.05$, a minimum of 31 patients was required in each group.

\section{Results}

In the 63 patients studied, a placebo adhesive tape was applied to 32 and transdermal ketoprofen was applied to 31. No patients refused to be interviewed. There were no significant differences among the groups in age, body weight, gender distribution, cuff pressure and duration of anesthesia (Table III). No patient was eliminated from the study because of difficult intubation.

The overall incidence of sore throat in the ketoprofen group was $32 \%$, compared with $50 \%$ in the control group (Table IV). The difference was not statistically significant.

The severity of sore throat was alleviated significantly in the ketoprofen group $(P<0.05)$. The number of patients with a score of 3 and 4 was markedly reduced in the ketoprofen group. In the control group, $23 \%$ of patients graded their sore throat a score of 3 or 4 , while $6 \%$ in the ketoprofen group (Table IV).

No effect on the skin was attributed to ketoprofen adhesive tape and the patients did not present any gastrointestinal complications at the time of interview. Postoperative bleeding did not increase during the hospitalization. 
TABLE I The questionnaire for evaluation for the sore throat postoperatively

Have you had a sore throat at all since the operation? Would you grade it according to this scale (Table II)? Have you had any discomfort on the skin of the neck? Have you had any discomfort in the upper abdomen?

TABLE II Scoring system for sore throat

Please grade any sore throat you may have experienced according to the following scale:

0 No sore throat or any throat discomfort at any time since the operation (until now).

1 Minimal by sore or scratchy throat occurring at any time since the operation.

2 Mild sore throat, less severe than noted with a cold, occurring at any time since the operation.

3 Moderate sore throat, similar to that noted with a cold, occurring at any time since the operation.

4 Severe sore throat, more severe than that noted with a cold, occurring at any time since the operation.

TABLE III Patient characteristics

\begin{tabular}{lll}
\hline & $\begin{array}{l}\text { Ketoprofen } \\
(n=31)\end{array}$ & $\begin{array}{l}\text { Control } \\
(n=32)\end{array}$ \\
\hline Age $(\mathrm{yr})$ & $53 \pm 11$ & $52 \pm 15$ \\
Gender $(\mathrm{M} / \mathrm{F})$ & $9 / 22$ & $8 / 24$ \\
ASA physical status (I/II) & $16 / 15$ & $14 / 18$ \\
Weight $(\mathrm{kg})$ & $59 \pm 8$ & $56 \pm 8$ \\
Cuff pressure $\left(\mathrm{cm} \mathrm{H}_{2} \mathrm{O}\right)$ & $19 \pm 4$ & $20 \pm 5$ \\
Duration of anesthesia $(\mathrm{min})$ & $197 \pm 58$ & $208 \pm 61$ \\
\hline
\end{tabular}

Values are mean \pm SD or numbers. No significant difference between groups.

TABLE IV Distribution of scores

\begin{tabular}{llllll}
\hline & \multicolumn{5}{c}{ No. of patients } \\
$n$ & score 0 & score 1 & score 2 & score 3 & score 4 \\
\hline Ketoprofen $(n=31)$ & $21(68)$ & $6(19)$ & $2(6)$ & $1(3)$ & $1(3)$ \\
Control $(n=32)$ & $16(50)$ & $4(13)$ & $5(16)$ & $3(10)$ & $4(13)$ \\
\hline
\end{tabular}

Values are $n(\%)$. Mann-Whitney $\mathrm{U}$ test, $P<0.05$.

\section{Discussion}

The main finding of this study is that transdermal ketoprofen reduced the severity of sore throat after general anesthesia with laryngoscopy and tracheal intubation. Although the incidence of sore throat in the ketoprofen group was not decreased significantly, its severity was markedly alleviated in the present study. To our knowledge, transdermal NSAID for the prevention of postoperative sore throat had not been investigated previously. However, several interventions destined to reduce postoperative sore throat have been proposed.

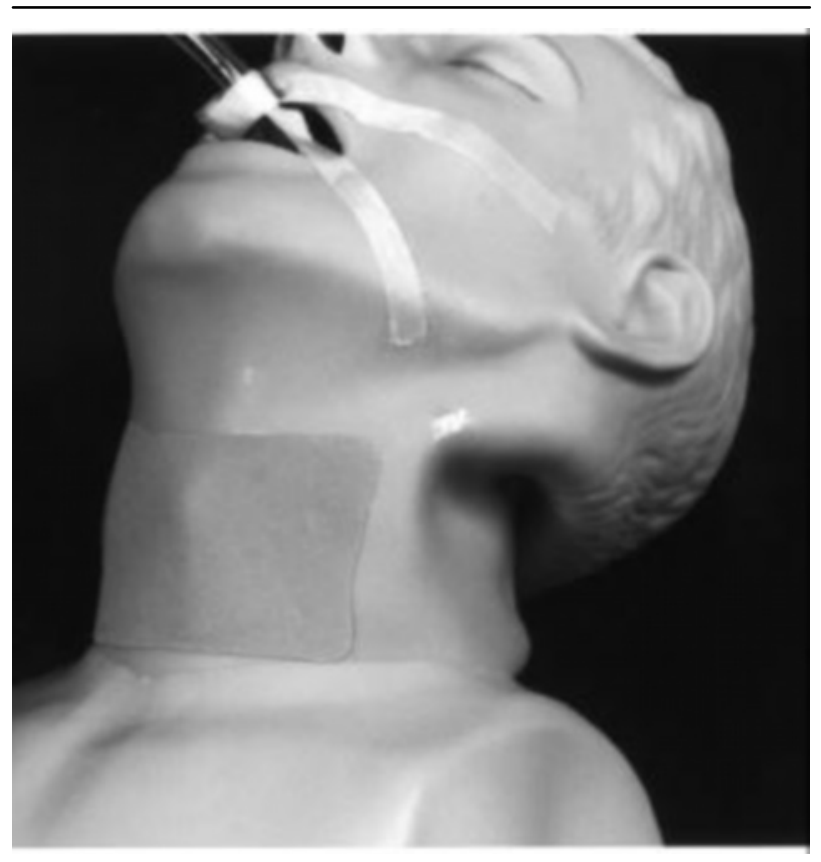

FIGURE The location of ketoprofen on the neck. After induction, a transdermal ketoprofen $20 \mathrm{mg}$ (Mohrus ${ }^{\circledR}$ tape) tape or a placebo tape was applied to the anterior skin of the neck.

El-Hakim studied the effect of a dose of beclomethasone inhaler $(50 \mu \mathrm{g})$ and lidocaine $10 \%$ spray on postoperative sore throat. A significant decrease in the incidence of sore throat was reported in the beclomethasone group (10\%) compared with the lidocaine group (55\%). ${ }^{15}$ Ayoub et al. reported that coating the endotracheal tube from the cuff to the $15-\mathrm{cm}$ mark with beclomethasone decreases sore throat. $^{14}$ Ketoprofen appears to show similar, favourable results.

Ketoprofen is a cyclooxygenase inhibitor, is said to stabilize lysosomal membranes and may antagonize the actions of bradykinin. ${ }^{2}$ Cordero et al. has reported that transdermal ketoprofen has a high permeation flux due to its high intrinsic solubility. ${ }^{19}$ These properties may be attributable to decreased inflammation as a result of ketoprofen application per se and lead to the reduction of sore throat. We chose the anterior skin of the neck for application of the drug because we expected that a higher local tissue concentration of ketoprofen would be achieved when applied in proximity to the larynx. However, the reduction of sore throat could be also due to the systemic absorption of ketoprofen, in which case the application to other sites may be also effective. Plus, it is unclear whether the treatment effect was obtained locally or systemically. It will be interesting to compare the benefits of trans- 
dermal application at different sites $v s$ the systemic administration by the usual $p o / p r / i v$ routes.

We conclude that postoperative sore throat is frequent in anesthetized patients undergoing routine endotracheal intubation and intraoperative transdermal ketoprofen applied over the larynx effectively mitigates this undesirable side effect.

Acknowledgements

We thank Yasuko Utsumi and Michael T. MacKay for their help and cooperation during this study.

\section{References}

1 Blanc VF, Tremblay NAG. The complications of tracheal intubation: a new classification with a review of the literature. Anesth Analg 1974; 53: 202-13.

2 Riding JE. Minor complications of general anaesthesia. Br J Anaesth 1975; 47: 91-101.

3 Shah MV, Mapleson WW. Sore throat after intubation of the trachea. Br J Anaesth 1984; 56: 1337-41.

4 Christensen AM, Willemoes-Larsen H, Lundby L, Jakobsen KB. Postoperative throat complaints after tracheal intubation. Br J Anaesth 1994; 73: 786-7.

5 Monroe MC, Gravenstein N, Saga-Rumley S. Postoperative sore throat: effect of oropharyngeal airway in orotracheally intubated patients. Anesth Analg 1990; 70: 512-6.

6 Seegobin RD, van Hasselt GL. Endotracheal cuff pressure and tracheal mucosal blood flow: endoscopic study of effects of four large volume cuffs. BMJ 1984; 288: 965-8.

7 Stanley $T H$. Nitrous oxide and pressures and volumes of high- and low-pressure endotracheal-tube cuffs in intubated patients. Anesthesiology 1975; 42: 637-40.

8 Saarnivaara L, Grahne B. Clinical study on an endotracheal tube with a high-residual volume, low- pressure cuff. Acta Anesthesiol Scand. 1981; 25: 89-92.

9 Jensen PJ, Hommelgaard P, Søndergaard P, Eriksen S. Sore throat after operation: influence of tracheal intubation, intracuff pressure and type of cuff. $\mathrm{Br} \mathrm{J}$ Anaesth 1982; 54: 453-7.

10 Mandøe H, Nikolajsen L, Lintrup U, Jepsen D, Molgaard J. Sore throat after endotracheal intubation. Anesth Analg 1992; 74: 897-900

11 Loeser EA, Bennett GM, Orr DL, Stanley TH Reduction of postoperative sore throat with new endotracheal tube cuffs. Anesthesiology 1980; 52: 257-9.

12 Thomas DV. Hoarseness and sore throat after tracheal intubation. Small tubes prevent (Letter). Anaesthesia 1993; 48: 355-6

13 Stenqvist $O$, Nilsson $K$. Postoperative sore throat related to tracheal tube cuff design. Can Anaesth Soc J 1982; 29: 384-6.
14 Ayoub CM, Ghobashy A, Koch ME, et al. Widespread application of topical steroids to decrease sore throat, hoarseness, and cough after tracheal intubation. Anesth Analg 1998; 87: 714-6.

15 El-Hakim M. Beclomethasone prevents postoperative sore throat. Acta Anaesthesiol Scand 1993; 37: 250-2

16 Fuller $P B$. The relationship between preintubation lidocaine and postanesthesia sore throat. J Am Ass Nurs Anesth 1992; 60: 374-8.

17 Fossgreen J. Ketoprofen. A survey of current publication. Scand J Rheumatol 1976; 14: 7-32.

18 Basto ER, Waintrop C, Mourey FD, Landru JP, Eurin $B G$, Jacob $L P$. Intravenous ketoprofen in thyroid and parathyroid surgery. Anesth Analg 2001; 92: 1052-7.

19 Cordero JA, Alarcon L, Escribano E, Obach R, Domenech J. A comparative study of the transdermal penetration of a series of nonsteroidal antiinflammatory drugs. J Pharm Sci 1997; 86: 503-8.

20 Nguyen Tu H, Saidi N, Lientand T, Bensaid S, Menival $V$, Duvaldestin P. Nitrous oxide increases endotracheal cuff pressre and the incidence of tracheal lesions in anesthetized patients. Anesth Analg 1999; 89: 187-90.

21 Harding CJ, McVey FK. Interview method affects incidence of postoperative sore throat. Anaesthesia 1987; 42: 1104-7.

22 Insel $P A$. Analgesic-antipyretics and antiinflammatory agents; drugs employed in the treatment of rheumatoid arthritis and gout. In: Gilman AG, Rall TW, Nies AS, Taylor P (Eds.). Goodman and Gilman's The Pharmacological Basis of Therapeutics, $8^{\text {th }}$ ed., New York: Pergamon Press, Inc., 1990: 638-81. 